\begin{tabular}{|l|l|}
\hline Postprint Version & 1.0 \\
\hline Journal website & http://www.springerlink.com/content/q3320325601415x7/ \\
\hline Pubmed link & http://www.ncbi.nlm.nih.gov/pubmed/21901499 \\
\hline DOI & $10.1007 /$ s10689-011-9479-1
\end{tabular}

This is a NIVEL certified Post Print, more info at http://www.nivel.eu

\title{
A pre-visit tailored website enhances counselees' realistic expectations and knowledge and fulfils information needs for breast cancer genetic counselling
}

\author{
AKKe AlbadA ${ }^{1}$, SANDRA VAN DULMEN ${ }^{1}$, DiCK LINDHOUT $^{2}$, JOZIEN M. BENSING $^{1},{ }^{3}$ AND \\ MARGREET G. E. M. AUSEMS ${ }^{2}$ \\ (1) NIVEL (Netherlands Institute for Health Services Research), P.O. Box 1568, 3500 BN Utrecht, The \\ Netherlands
}

(2) Department of Medical Genetics, University Medical Center Utrecht, Utrecht, The Netherlands

(3) Department of Health Psychology, Utrecht University, Utrecht, The Netherlands

\begin{abstract}
Counselees who are the first in their family to request breast cancer genetic counselling often don't know what to expect or have unrealistic expectations of genetic counselling. Receiving tailored information might help them to prepare for their first visit. We conducted a study of the effects of a pre-visit website providing computer-tailored information (E-info gene ${ }^{\text {ca }}$ ), on counselees' expectations, knowledge about breast cancer and heredity and information needs. Counselees were randomized to receive usual care (UC) or UC plus website. All counselees completed a baseline questionnaire and those randomized to the intervention group also completed a questionnaire after having viewed the website. After having accessed E-info gene $^{\text {ca }}$ counselees $(n=101)$ better knew what to expect of their first visit $\left(\chi^{2}=4.43 ; P=.04\right)$ and less often showed unrealistic expectations about possibilities for DNA-testing $\left(\chi^{2}=4.84\right.$; $\mathrm{P}=.03)$ than counselees in the UC group $(\mathrm{n}=89)$. In addition, the website increased counselees' knowledge of breast cancer and heredity $(\mathrm{B}=.23 ; \mathrm{P}=.003)$ and lowered their information needs $(\mathrm{B}=-.16 ; \mathrm{P}=.000)$ compared to the UC group. Especially, information concerning procedural aspects and emotional consequences of genetic counselling was considered less important. This study showed that counselees know more and need less when they are provided with extended pre-visit information through a tailored website and counselees enter the visit with more realistic expectations of genetic counselling. This might facilitate and focus communication within the subsequent consultation.
\end{abstract}

\section{INTRODUCTION}

Increasingly breast cancer patients and their family members attend genetic counselling because they want to be informed about the genetic nature of the disease, their own and/or their children's risk and to receive surveillance advice [1-4]. Breast cancer genetic counselling aims to educate about these topics $[5,6]$. 
However, a primary challenge for genetic counsellors is to communicate with counselees who do not know what to expect or have unrealistic expectations $[7,8]$.

Breast cancer genetic counselling consists of one to three visits. During the first visit, the occurrence of breast cancer and other cancers in the family is explored. This visit is mainly educative; counsellors explain the prevalence, indicators and inheritance of hereditary breast cancer, possibilities and limitations of diagnostic DNA-testing and the meaning of being carrier of a BRCA1/2 gene mutation [9]. Based on counselees' personal and family history of cancer, the likelihood that hereditary cancer is running in the family is estimated. Within most European countries and Australia, counselees may opt for a diagnostic DNA-test of the BRCA1/2 genes only after receiving an indication from the counsellor [10]. If there is no indication for diagnostic DNA-testing, the visit will include a risk estimation for the counselee and first degree family members and advice for surveillance when appropriate. If the counselee is opting for DNAtesting or confirmation of medical data from affected family members is needed, a second visit will follow. This second visit may serve to disclose DNA-test results, to further discuss the family medical history, or to discuss the option for DNA-testing. About two-third of all counselees is indicated for a follow-up visit [9].

Probands typically are unsure about what to expect from genetic counselling or have unrealistic expectations $[11,12]$. They expect to be offered a DNA-test independent of their disease status and risk profile $[7,13,14]$ and expect a clear-cut result about whether the breast cancer in their family is hereditary $[15,16]$. However, the presence of hereditary cancer can not be ruled out, it can only be confirmed when a BRCA1/2 mutation is found. These unrealistic expectations need to be corrected during the first visit. Also, counselees pre-visit levels of knowledge about breast cancer and heredity show considerable scope for improvement, e.g. many women are unaware of modes of inheritance and incomplete penetrance $[17,18]$. Generally, lay knowledge about hereditary breast cancer, autosomal dominant inheritance and possibilities of DNA-testing is poor [19-23] and therefore counsellors need to invest a large part of the consultation in explaining these topics $[24,25]$. This results in large amounts of standard information transferred in the consultation $[8,9]$ and reduces the time available for discussing whether the counselee wants to be tested, the psychosocial consequences of testing and communication with family members. Consequently, counselees still report unfulfilled needs post-visit [26].

Provision of pre-visit information might help counselees to better prepare themselves for genetic counselling, which might increase realistic expectations and decrease information needs. Counselees have difficulties finding information [27]. While there is information on the internet, they find it difficult to decide whether it is reliable and applicable to them [28] and they prefer information from their hospital [29]. Information tailored to the individual increases the expected effects, since tailored information is perceived as more personally relevant [30], stimulates cognitive activity [31,32] and is better recalled than generic information [33-36]. Web-based pre-visit information has shown to increase counselees' knowledge about breast cancer and heredity. It was however never evaluated as whether counselees felt the information prepared them for genetic counselling and whether it fulfilled their needs [37-39]. Evaluation of effects on counselees' expectations and information needs derived from the counselees' perspective is thus needed [25].

Therefore, the current study investigated whether access to a website with computer-tailored information increased counselees' realistic expectations, breast cancer knowledge and decreased their information needs. This website, called E-info gene ${ }^{\mathrm{ca}}$, provided extended information about genetic counselling and hereditary breast cancer, which was tailored to the individual counselee based on a number of characteristics e.g. her risk of being a carrier of a BRCA1/2 gene mutation [40]. Additionally, we studied whether time spent on the website influenced improvements in knowledge and information needs, as longer use is likely to increase learning [41, 42].

\section{METHODS}

\section{Study design}

This study was conducted at the department of Medical Genetics of the University Medical Center Utrecht (UMCU). Consecutive new counselees were included from February 2008 to April 2010 (Fig. 1). Adult female counselees who were the first of their first degree family to seek breast cancer genetic counselling received information about the study and an opt-out form. The opt-out form included a question about reasons of withdrawal. Counselees were ineligible if they lacked internet or email access or when they requested presymptomatic DNA-testing because of an identified BRCA1/2 gene mutation in a relative. All 
counselees who did not return the opt-out form were allocated to the usual care (UC) or intervention group $\left(\mathrm{UC}+\right.$ website E-info gene $\left.{ }^{\mathrm{ca}}\right)$ by use of sequentially numbered, sealed, opaque envelopes. UC comprised of a brief standard leaflet with information about the genetic counselling procedure. Counselees received a login to access the web-based baseline questionnaire a week before their first visit (T0). Upon completion the intervention group respondents received a link to access E-info gene ${ }^{\text {ca }}$. Directly after having viewed Einfo gene ${ }^{\text {ca }}$ they completed the post-website questionnaire (T1). The study was approved by the medical ethical committee of the UMCU and was registered in the Netherlands Trial Register (ISRCTN82643064).

\section{[FIGURE 1]}

\section{E-info gene ${ }^{\text {ca }}$}

The pre-visit website, called E-info gene ${ }^{\mathrm{ca}}$, provided extensive information about the genetic counselling procedure, hereditary breast cancer, surveillance, DNA-testing, the meaning of being carrier of a cancer gene and emotional consequences of genetic counselling. These topics were based on a needs assessment [14]. The information was tailored to the individual counselee based on her age, disease status, whether she had children and her risk of being a carrier of a BRCA1/2 gene mutation. A high risk of being a mutation carrier meant that there was a chance of $10 \%$ or more that a BRCA1/2 mutation was present in the counselee or an affected family member, implying an indication for diagnostic DNA-testing. An algorithm for this risk included personal and family medical history (see Table 1) and was based on the Dutch national guidelines on diagnostics for hereditary cancers [43]. E-info gene ${ }^{\text {ca }}$ did not offer information on the risk for the individual counselee, as the website was meant as preparation for the face-to-face counselling. The website has been described in full elsewhere [40].

\section{[TABLE 1]}

\section{Counselee characteristics}

Age, whether the counselee had children, educational attainment, disease status, type of referral, initiative for the referral and whether first degree family members had (had) breast cancer were collected at $\mathrm{T} 0$.

\section{Outcome measures}

Counselees' expectations were assessed with an open question, 'What do you expect from your appointment at the department of Medical Genetics?' This was the last question of T0 for the UC group and the first question of $\mathrm{T} 1$ for the intervention group. Both $\mathrm{T} 0$ and $\mathrm{T} 1$ questionnaires included an assessment of the level of accurate knowledge about breast cancer and heredity with 7 items [18, 44]. Respondents indicated whether each item was correct, incorrect, or whether they did not know. An accurate knowledge score was computed as the number of correct answers. At T1 additionally, knowledge about the need for an indication for DNA-testing and the possibility of an inconclusive DNA-test outcome was assessed with two items. Finally, information needs were assessed at T0 and T1 with the QUOTE-gene ${ }^{\mathrm{ca}}[14]$. The items referred to explanations counselees wanted to receive during the first consultation and were answered on a 4-point scale (not important to extremely important). Earlier identified factors were used to summarize data (Table 4) [14].

\section{Process measures}

Usage of E-info gene ${ }^{\text {ca }}$ was recorded with web tracking services. Process analyses showed that counselees viewed on average 11 of the 19 web pages and spent a median of 14 min on E-info gene ${ }^{\text {ca }}$ [45].

\section{Analysis}

Counselees' answers to the open question about their expectations of the consultation were contentanalyzed based on the items of the QUOTE-gene ${ }^{\text {ca }}$ (see Table 4). The coders were blinded for the intervention/UC condition. The first $30 \%$ of the responses were coded independently by both the first (AA) and the last author (MA). Agreement between coders was $80 \%$. Disagreements were discussed and AA coded the remaining $70 \%$ of the responses. Additionally, both raters coded all answers to assess whether the 
expectation was (partly) realistic or unrealistic concerning the counselling process, possibilities for and possible results of DNA-testing. Disagreements were discussed until consensus was achieved.

To check for baseline differences between the study groups, $\chi^{2}$ and $t$ tests were performed. To check for between-group differences we conducted $\chi^{2}$ and multivariate regression analyses controlled for counselees' age, disease status, educational level, whether they had children and baseline levels. We conducted proportion tests and paired $t$ tests to check for within-group differences of the intervention group (T0-T1). Two-sided tests of significance were performed and results were considered statistically significant when $\mathrm{P}<.05$. Cohen's D effect sizes were calculated. Additionally, multivariate linear regression analyses were conducted for knowledge and needs at T1 with time spent on E-info gene ${ }^{\text {ca }}$, baseline levels and counselee characteristics as independent variables. All analyses were conducted with Stata 10.

We compared the outcomes of two intention-to-treat analyses with an available case analysis for the effects of the website on the overall knowledge score and information needs [46]. The intention-to-treat analyses included all 190 cases with complete data at baseline (Fig. 1). Firstly, baseline outcomes were taken forward for the drop-outs. Secondly, we conducted regression imputation with random residuals.

\section{RESULTS}

\section{Response}

As shown in Fig. 1, few counselees were ineligible because of lack of internet or email access (24 of 371 ; $6.5 \%$ ). The response was $58.6 \%$. Half of the decliners gave a reason (72 of $139 ; 50.4 \%)$. Most preferred the visit not to be videotaped ( 46 of 72; 65.7\%), which was part of the larger study. There were no significant differences between participants and decliners in age $(\mathrm{t}=1.62 ; \mathrm{P}=.11)$, disease status $\left(\chi^{2}=.05 ; \mathrm{df}=1\right.$; $\mathrm{P}=.81)$, family history of cancer $\left(\chi^{2}=.06 ; \mathrm{df}=1 ; \mathrm{P}=.82\right)$ and referral pathway $\left(\chi^{2}=87 ; \mathrm{df}=1 ; \mathrm{P}=.35\right)$.

\section{Counselee characteristics}

As shown in Table 1, UC and intervention group respondents were similar with regard to age, having children, educational attainment, referral pattern and the risk of being a carrier of a BRCA1/2 mutation. However, the intervention group respondents tended to be affected more often with breast cancer themselves $\left(\chi^{2}=3.84 ; \mathrm{df}=1 ; \mathrm{P}=.053\right)$. Therefore, we checked the association between having (had) breast cancer and baseline knowledge $(\mathrm{t}=.12 ; \mathrm{P}=.91)$ and controlled all analyses for disease status. One counselee was affected with ovarian cancer. There were no significant baseline differences in knowledge and information needs between the groups (Table 3).

\section{Drop-out}

All 101 intervention group respondents accessed E-info gene ${ }^{\text {ca }}, 7$ viewed only the homepage. Sixteen (15.84\%) did not complete the T1 questionnaire (drop-out). Amongst them were five of the respondents who had viewed only the homepage and therefore their baseline knowledge and information needs values were taken forward to T1. The other 11 drop-outs visited the website for on average 40:03 (min:sec), which is almost twice as long than the mean duration of 21:05 of all 101 intervention group counselees. Their baseline knowledge score was $3.82(\mathrm{SD}=1.54)$, which is .82 lower than the mean of the intervention group (Table 3). These drop-outs were not included in the available case analysis.

Comparison of the outcomes with the conservative (baseline values forwarded) and regression imputation (predicted values imputed) intention-to-treat analyses showed that the intervention effects on the overall knowledge score, the information needs score and the need for information about procedural and emotional aspects of counselling were statistically significant for all three analyses, with smallest effect sizes in the conservative intention-to-treat analysis and largest effect sizes in the regression imputation intention-totreat analysis. The conservative intention-to-treat analysis is likely to underestimate the effects because progress due to website visit was assumed to be zero [47]. The regression imputation resulted in the largest intervention effects. The available case analysis might thus give a small underestimation of the intervention effects and we therefore choose to report the results of this analysis as a relatively conservative approach.

\section{Expectations of genetic counselling}

More UC group than intervention group respondents indicated that they did not know what to expect of genetic counselling $\left(\chi^{2}=4.43 ; \mathrm{df}=1 ; \mathrm{P}=.04\right.$; Table 2$)$. The other counselees wrote down an expectation and these were more often (partly) unrealistic in the UC than the intervention group. In the UC group 13 counselees expected to have a DNA-test irrespective of their risk profile, compared to four intervention 
group respondents $\left(\chi^{2}=4.84 ; \mathrm{df}=1 ; \mathrm{P}=.03\right)$. Respondents in the $\mathrm{UC}$ group tended to more often expect certainty about whether they were a carrier of a hereditary breast cancer gene than intervention group respondents $\left(\chi^{2}=3.08 ; \mathrm{df}=1 ; \mathrm{P}=.08\right)$. Another expectation classified as unrealistic was "getting certainty about whether the breast cancer in our family is hereditary or not". Frequency of this unrealistic expectation was similar in the UC and intervention group.

\section{[TABLE 2]}

Eight intervention group respondents mentioned a particularly realistic expectation, namely to find out whether there would be an indication for DNA-testing in their family, compared to none of the UC group respondents $\left(\chi^{2}=7.36 ; \mathrm{df}=1 ; \mathrm{P}=.007\right)$. Counselees also expected to receive information, mainly about their own and their family members' risks. The intervention group respondents significantly less often expected to receive information about the procedure of genetic counselling and about indications for hereditary breast cancer.

\section{Knowledge of breast cancer and heredity}

After having accessed the website, counselees had more knowledge of breast cancer and heredity compared to the $\mathrm{UC}$ group $(\mathrm{B}=.23 ; \mathrm{P}=.003)$. The intervention group had increased their knowledge by reading the website, with a Cohen's $\mathrm{D}$ of .43 , which is a medium effect size $(\mathrm{t}=4.25 ; \mathrm{P}=.000)$. Counselees had particularly gained knowledge concerning inheritance and penetrance of BRCA1/2 mutations (Table 3). The largest increase in knowledge concerned the chance to inherit a BRCA1/2 mutation via a father who is carrier. Additionally, after having accessed the website, the majority of counselees $(67,80.72 \%)$ knew that a DNA-test is not always indicated, and most (73.53\%) of the counselees at high risk of being a mutation carrier were aware of the fact that a DNA-test can give an inconclusive test result.

\section{[TABLE 3]}

Multivariate analysis showed that only educational level predicted baseline knowledge $(\mathrm{B}=.19 ; \mathrm{P}=.01)$. Less highly educated counselees levelled up their knowledge by using E-info gene ${ }^{\text {ca }}$, as knowledge at T1 was unrelated to education $(\mathrm{B}=.06 ; \mathrm{P}=.58)$. Analysis of knowledge at $\mathrm{T} 1$ controlled for baseline values showed that older counselees tended to benefit less from the website $(\mathrm{B}=-.17 ; \mathrm{P}=.08)$. Time spent on the website was not associated with knowledge gain $(\mathrm{B}=.03 ; \mathrm{P}=.75)$. However, there were several relations between website use and knowledge gain per item. First, duration of having viewed the page about inheritance predicted knowledge gain concerning paternal inheritance of hereditary breast cancer $(\mathrm{B}=.28$; $\mathrm{P}=.001)$. Second, those who viewed the webpage about the meaning of being a carrier of a BRCA1/2 mutation tended to have more knowledge concerning the penetrance of those mutations $(\mathrm{B}=.14 ; \mathrm{P}=.09)$. And third, counselees who had viewed the webpage about possible results of DNA-testing were more often aware of the possibility of an inconclusive test result $\left(\chi^{2}=22.3 ; \mathrm{df}=1 ; \mathrm{P}=.000\right)$.

\section{Information needs}

After having accessed the website E-info gene ${ }^{\text {ca }}$, counselees had significantly lower information needs compared to the UC group $(\mathrm{B}=-.16 ; \mathrm{P}=.000)$. Overall information needs of intervention group counselees had decreased with a Cohen's $\mathrm{D}$ of $.32(\mathrm{t}=-3.59 ; \mathrm{P}=.001)$. Table 4 describes the factors and items for pre-visit information needs. At T1, the intervention group counselees had significantly lower needs for information about procedural aspects of counselling $(\mathrm{d}=.16)$ and there was a trend towards decreased needs for information about determination and meaning of being carrier of a cancer gene compared to baseline $(d=.19)$. Additionally, information needs about emotional aspects for the counselee and her family had significantly decreased, the Cohen's D for this factor was .37. Concerning the heredity of breast cancer, the effect size was medium (.21), but the information needs only decreased for the topic of inheritance and not for the topic of prevalence. However, the need for information about prevalence tended to be lower if the web page about prevalence was viewed longer $(\mathrm{B}=-.16 ; \mathrm{P}=.07)$. The need for information about the own risk of developing cancer and screening options did not significantly decrease. 


\section{[TABLE 4]}

\section{DISCUSSION}

This is the first study of the effects of a pre-visit tailored website on counselees' realistic expectations of breast cancer genetic counselling and their feeling of information needs being addressed [48]. The study found positive effects on both these expectations and needs. Additionally, the study confirms previous findings that pre-visit web-based education enhanced breast cancer knowledge [33, 37-39] and this result is consistent with the established positive relationship between web-based patient education and knowledge levels $[48,49]$. Now that a large majority of the counselees $(94 \%)$ and of the general population $(90 \%$ in the Netherlands and $74 \%$ in the USA) $[50,51]$ has access to the internet, it is feasible to provide web-based education. As extended pre-visit information does not seem to be provided routinely [11,52], the results of this study hold advice for other cancer genetics centres. These show promise of a pre-visit tailored website as a way that genetic counselling can become more efficient without compromising the quality of care [25, 53].

First, results suggest that counselees better knew what to expect after having visited the website. Counselees in particular had more realistic expectations of possibilities for DNA-testing, i.e. not expecting a DNA-test irrespective of their risk profile. Additionally, counselees in the intervention group less often expected to receive information about the genetic counselling procedure and about indications of hereditary breast cancer during the visit, compared to the UC group. This improvement in counselees' expectations might limit their disappointment in case the risk assessment in the consultation does not result in an indication for DNA-testing in their family.

Second, after having read the website E-info gene ${ }^{\text {ca }}$ counselees in the intervention group had significantly higher levels of accurate breast cancer knowledge than the UC group. Counselees learned to avoid common mistakes, such as the negligence of inheritance through the father's pedigree and the assumption that all carriers will develop breast cancer. Since this study lacked a comparison group receiving non-tailored extended information, we can not disentangle the effects of the information being extended and tailored. However, given the evidence for effectiveness of computer-tailored information it seems plausible that tailoring has contributed to the effects [30, 33, 35, 54]. Moreover, tailored information has been found to enhance recall in cancer patients [55].

Third, the pre-visit tailored website significantly lowered counselees' information needs, especially concerning procedural and emotional aspects of counselling and determination and meaning of being carrier of a breast cancer gene. These improvements might alleviate the strain of education about the procedure of genetic counselling and DNA-testing within the first visit [56]. Also, the more realistic expectations and alleviated information needs might facilitate more in-depth and interactive discussion about the counselee's risk, whether she considers DNA-testing, emotional consequences for herself and her family members and communication with these relatives [57]. The need for information related to the own breast cancer risk remained counselees' priority and should thus be the main focus of the first visit.

Lastly, time spent on the website was not significantly associated with the overall knowledge score, but more time spent on the web page about inheritance significantly increased counselees' knowledge about inheritance through the paternal side.

\section{Strengths and limitations}

The website studied in the current report was integrated in everyday clinical practice and counselees accessed the website from their homes. This is promising for future implementation outside the study context [58] and limits bias to participation. There are some limitations. First, this was a mono-centre study. However, the UC condition consisting of a brief generic leaflet is comparable to the pre-visit information of other centres, as both nationally and internationally, centres do not seem to provide extended pre-visit information $[4,7,11,52]$. Second, the full intention-to-treat analysis with imputed predicted values might result in a more accurate estimation of the effect size [47]. However, we choose to present the available case analysis. This might have resulted in a small underestimation rather than an overestimation of intervention effects. Third, the knowledge scale showed a ceiling effect. On at least two of the items hardly any improvements from baseline were possible and this might have hampered the effect size. Furthermore, based on the use of the breast cancer knowledge scale in prior studies [18, 44, 59], the learning effect of filling in the scale alone is negligible and could thus not bias the current study. Repeated measures of the scale show a gradual decrease in knowledge over time instead of an increase due to a learning effect [59]. 
However, completing the knowledge items could have enabled intervention group counselees to better process the website information, because the questions made them aware of their lack of knowledge. Educational websites could provide information in a feedback format, i.e. show the counselee's answer and provide explanation on the right answer, which was shown to enhance learning [60]. And finally, further study should investigate the longer-term impact of pre-visit education.

\section{CONCLUSION}

This study showed that counselees enter their first visit for breast cancer genetic counselling with more realistic expectations of genetic counselling if they are provided with extended pre-visit information through a tailored website. Additionally, these counselees know more and need less information. Use of a pre-visit tailored website might therefore reduce disappointment about the need for an indication for DNAtesting, reduce the amount of standard information to be transferred in the consultation and increase the time available for discussion of the counselee's risk perception, emotional issues and communication with relatives.

\section{ACKNOWLEDGMENTS}

We want to thank all counselees who participated in this study. We also owe our gratitude to the clinical geneticists, genetic counsellors and residents in clinical genetics of the department of Medical Genetics of the UMC Utrecht, in particular, Angela Schoemaker and Ivette Wieffer who arranged the logistics of the study. We are grateful to Anita Wallet and Doortje Saya for organizing many practicalities of the study. This study was funded by a grant from the Dutch Cancer Society (Nivel 2006-3469).

\section{REFERENCES}

1. Julian-Reynier CJ, Eisinger F, Chabal F, Aurran Y, Bignon YJ, Noguès C, Machelard-Roumagnac M, Maugard C, Vennin P, Sobol H (1998) Cancer genetic clinics: why do women who already have cancer attend? Eur J Cancer 34(10):1549-1553

2. Epplein M, Koon KP, Ramsey SD, Potter JD (2005) Genetic services for familial cancer patients: a follow-up survey of National Cancer Institute Cancer Centers. J Clin Oncol 23(21):4713-4718

3. Brain K, Gray J, Norman P, Parsons E, Clarke A, Rogers C, Mansel R, Harper P (2000) Why do women attend familial breast cancer clinics? J Med Genet 37(3):197-202

4. Van Asperen CJ, Van Dijk S, Zoeteweij MW, Timmermans DR, De Bock GH, Meijers-Heijboer EJ, Niermeijer MF, Breuning MH, Kievit J, Otten W (2002) What do women really want to know? Motives for attending familial breast cancer clinics. J Med Genet 39(6):410-414

5. Robson ME, Storm CD, Weitzel J, Wollins DS, Offit K (2010) American Society of Clinical Oncology policy statement update: genetic and genomic testing for cancer susceptibility. J Clin Oncol 28(5):893-90

6. Biesecker BB (2001) Goals of genetic counseling. Clin Genet 60(5):323-330

7. Hallowell N, Murton F, Statham H, Green JM, Richards MPM (1997) Women's need for information before attending genetic counselling for familial breast or ovarian cancer: a questionnaire, interview, and observational study. Br Med J 314:281-283

8. Pieterse AH, Van Dulmen AM, Ausems MGEM, Beemer FA, Bensing JM (2005) Communication in cancer genetic counselling: does it reflect counselees' pre-visit needs and preferences? $\mathrm{Br} \mathrm{J}$ Cancer 92(9):1671-1678

9. Meiser B, Irle J, Lobb E, Barlow-Stewart K (2008) Assessment of the content and process of genetic counseling: a critical review of empirical studies. J Genet Counsel 17:434-451

10. Meiser B, Gaff C, Julian-Reynier C, Biesecker BB, Esplen MJ, Vodermaier A, Tibben A (2006) International perspectives on genetic counseling and testing for breast cancer risk. Breast Dis 27:109125

11. Metcalfe A, Werrett J, Burgess L, Clifford C (2007) Psychosocial impact of the lack of information given at referral about familial risk for cancer. Psychooncology 16(5):458-465

12. Bernhardt BA, Biesecker BB, Mastromarino CL (2000) Goals, benefits, and outcomes of genetic counseling: client and genetic counselor assessment. Am J Med Genet 94(3):189-197

13. Sweet KM, Willis SK, Ashida S, Westman JA (2003) Use of fear-appeal techniques in the design of tailored cancer risk communication messages: implications for healthcare providers. J Clin Oncol 21(17):3375-3376 
Albada, A., Dulmen, S. van, Lindhout, D., Bensing, J.M., Ausems, M.G.E.M. A pre-visit tailored website enhances counselees' realistic expectations and knowledge and fulfils information needs for breast cancer genetic counselling. Familial Cancer: 2012, 11(1), 85-95

14. Pieterse A, Van Dulmen S, Ausems M, Schoemaker A, Beemer F, Bensing J (2005) QUOTEgene $^{\text {ca. }}$ : development of a counselee-centered instrument to measure needs and preferences in genetic counseling for hereditary cancer. Psychooncology 14(5):361-375

15. Frost CJ, Venne V, Cunningham D, Gerritsen-McKane R (2004) Decision making with uncertain information: learning from women in a high risk breast cancer clinic. J Genet Couns 13:221-236

16. Press NA, Yasui Y, Reynolds S, Durfy SJ, Burke W (2001) Women's interest in genetic testing for breast cancer susceptibility may be based on unrealistic expectations. Am J Med Genet 99:99-110

17. Meiser B, Butow P, Baratt A, Gattas M, Gaff C, Haan E, Gleeson M, Dudding T, Tucker K, the Psychological Impact Collaborative Group (2001) Risk perceptions and knowledge of breast cancer genetics in women at increased risk of developing hereditary breast cancer. Psychol Health 16(3):297311

18. Pieterse AH, Ausems MGEM, Van Dulmen AM, Beemer FA, Bensing JM (2005) Initial cancer genetic counseling consultation: change in counselees' cognitions and anxiety, and association with addressing their needs and preferences. Am J Med Genet A 137(1):27-35

19. Henneman L, Timmermans DR, Van der Wal G (2004) Public experiences, knowledge and expectations about medical genetics and the use of genetic information. Community Genet 7(1):33-43

20. Calsbeek H, Morren M, Bensing J, Rijken M (2007) Knowledge and attitudes towards genetic testing: a two year follow-up study in patients with asthma, diabetes mellitus and cardiovascular disease. J Genet Couns 16(4):493-504

21. Morren M, Rijken M, Baanders AN, Bensing J (2007) Perceived genetic knowledge, attitudes towards genetic testing, and the relationship between these among patients with a chronic disease. Patient Educ Couns 65(2):197-204

22. Mesters I, Ausems A, De Vries H (2005) General public's knowledge, interest and information needs related to genetic cancer: an exploratory study. Eur J Cancer Prev 14(1):69-75

23. Walter FM, Emery J, Braithwaite D, Marteau TM (2004) Lay understanding of familial risk of common chronic diseases: a systematic review and synthesis of qualitative research. Ann Fam Med 2:583-594

24. Butow P, Lobb E (2004) Analyzing the process and content of genetic counseling in familial breast cancer consultations. J Genet Couns 13(5):403-424

25. Wang C, Gonzalez R, Merajver SD (2004) Assessment of genetic testing and related counseling services: current research and future directions. Soc Sci Med 58(7):1427-1442

26. Pieterse AH, Van Dulmen AM, Beemer FA, Bensing JM, Ausems MGEM (2007) Cancer genetic counseling: Communication and counselees' post-visit satisfaction, cognitions, anxiety, and needs fulfillment. J Genet Couns 16(1):85-96

27. Metcalfe A, Werrett J, Burgess L, Chapman C, Clifford C (2009) Cancer genetic predisposition: information needs of patients irrespective of risk level. Fam Cancer 8:403-412

28. Pereira JL, Koski S, Hanson J, Bruera ED, Mackey JR (2000) Internet usage among women with breast cancer: an exploratory study. Clin Breast Cancer 1(2):148-153

29. Van de Poll-Franse LV, Van Eenbergen MC (2008) Internet use by cancer survivors: current use and future wishes. Support Care Cancer 16(10):1189-1195

30. Brug J, Steenhuis I, Van Assema P, de Vries H (1996) The impact of a computer-tailored nutrition intervention. Prev Med 25(3):236-242

31. Petty R, Cacioppo J (1986) The elaboration likelihood model of persuasion. Adv Exp Soc Psychol 19:123-205

32. Hawkins RP, Kreuter M, Resnicow K, Fishbein M, Dijkstra A (2008) Understanding tailoring in communicating about health. Health Educ Res 23(3):454-466

33. Skinner CS, Schildkraut JM, Berry D, Calingaert B, Marcom PK, Sugarman J, Winer EP, Iglehart JD, Futreal PA (2002) Pre-counseling education materials for BRCA testing: does tailoring make a difference? Genet Test 6(2):93-105

34. Albada A, Ausems MGEM, Bensing JM, Van Dulmen S (2009) Tailored information about cancer risk and screening: a systematic review. Patient Educ Couns 77(2):155-171

35. Campbell MK, DeVellis BM, Strecher VJ, Ammerman AS, DeVellis RF, Sandler RS (1994) Improving dietary behavior: the effectiveness of tailored messages in primary care settings. Am J Public Health 84(5):783-787

36. Jones R, Pearson J, McGregor S, Cawsey AJ, Barrett A, Craig N, Atkinson JM, Gilmour WH, McEwen J (1999) Randomised trial of personalised computer based information for cancer patients. BMJ 319(7219):1241-1247 
Albada, A., Dulmen, S. van, Lindhout, D., Bensing, J.M., Ausems, M.G.E.M. A pre-visit tailored website enhances counselees' realistic expectations and knowledge and fulfils information needs for breast cancer genetic counselling. Familial Cancer: 2012, 11(1), 85-95

37. Cull A, Miller H, Porterfield T, Mackay J, Anderson ED, Steel CM, Elton RA (1998) The use of videotaped information in cancer genetic counselling: a randomized evaluation study. $\mathrm{Br} \mathrm{J}$ Cancer 77(5):830-837

38. Green MJ, Peterson SK, Baker MW, Harper GR, Friedman LC, Rubinstein WS, Mauger DT (2004) Effect of a computer-based decision aid on knowledge, perceptions, and intentions about genetic testing for breast cancer susceptibility: a randomized controlled trial. JAMA 292(4):442-452

39. Green MJ, Peterson SK, Baker MW, Friedman LC, Harper GR, Rubinstein WS, Peters JA, Mauger DT (2005) Use of an educational computer program before genetic counseling for breast cancer susceptibility: effects on duration and content of counseling sessions. Genet Med 7(4):221-229

40. Albada A, Van Dulmen S, Otten R, Bensing JM, Ausems MGEM (2009) Development of E-info gene(ca): a website providing computer-tailored information and question prompt prior to breast cancer genetic counseling. J Genet Counsel 18(4):326-338

41. Wantland DJ, Portillo CJ, Holzemer WL, Slaughter R, McGhee EM (2004) The effectiveness of Web-based vs. non-Web-based interventions: a meta-analysis of behavioral change outcomes. J Med Internet Res 6(4):e40

42. Nguyen HQ, Carrieri-Kohlman V, Rankin SH, Slaughter R, Stulbarg MS (2004) Internet-based patient education and support interventions: a review of evaluation studies and directions for future research. Comput Biol Med 34(2):95-112

43. STOET, Association Clinical Genetics Netherlands, Working group Clinical Oncogenetics (2005) Hereditary tumours: guidelines for diagnostics and prevention. [Erfelijke tumoren: Richtlijnen voor diagnostiek en preventie]. STOET, Leiden

44. Claes E, Evers-Kiebooms G, Boogaerts A, Decruyenaere M, Denayer L, Legius E (2003) Communication with close and distant relatives in the context of genetic testing for hereditary breast and ovarian cancer in cancer patients. Am J Med Genet 116A(1):11-19

45. Albada A, Ausems MGEM, Otten R, Bensing JM, Van Dulmen S (2011) Use and evaluation of an individually tailored website for counselees prior to breast cancer genetic counselling. J Cancer Educ (in press)

46. Spratt M, Carpenter J, Sterne JA, Carlin JB, Heron J, Henderson J, Tilling K (2010) Strategies for multiple imputation in longitudinal studies. Am J Epidemiol 172(4):478-487

47. Wood AM, White IR, Hillsdon M, Carpenter J (2005) Comparison of imputation and modelling methods in the analysis of a physical activity trial with missing outcomes. Int J Epidemiol 34(1):89-99

48. Ryhanen AM, Siekkinen M, Rankinen S, Korvenranta H, Leino-Kilpi H (2010) The effects of Internet or interactive computer-based patient education in the field of breast cancer: a systematic literature review. Patient Educ Couns 79(1):5-13

49. McPherson CJ, Higginson IJ, Hearn J (2001) Effective methods of giving information in cancer: a systematic literature review of randomized controlled trials. J Public Health Med 23(3):227-234

50. RVZ (2010) Health 2.0. Dutch Council for Public Health and Health Care (RVZ), The Hague

51. US Census Bureau (2009) Internet use in the United States.

http://www.census.gov/population/www/socdemo/computer/2009.html. Cited 20 Dec 2010

52. Stopfer JE (2000) Genetic counseling and clinical cancer genetics services. Semin Surg Oncol 18(4):347-357

53. Eysenbach G, Diepgen TL (2001) The role of e-health and consumer health informatics for evidence-based patient choice in the 21st century. Clin Dermatol 19(1):11-17

54. Noar SM, Benac CN, Harris MS (2007) Does tailoring matter? Meta-analytic review of tailored print health behavior change interventions. Psychol Bull 133(4):673-693

55. Van der Meulen N, Jansen J, Van Dulmen S, Bensing J, Van Weert J (2008) Interventions to improve recall of medical information in cancer patients: a systematic review of the literature. Psychooncology 17:857-868

56. Wakefield CE, Meiser B, Homewood J, Peate M, Taylor A, Lobb E, Kirk J, Young MA, Williams R, Dudding T, Tucker K (2008) A randomized controlled trial of a decision aid for women considering genetic testing for breast and ovarian cancer risk. Breast Cancer Res Treat 107(2):289-301

57. Vos J, Menko F, Jansen AM, Van Asperen CJ, Stiggelbout AM, Tibben A (2011) A whisper-game perspective on the family communication of DNA-test results: a retrospective study on the communication process of BRCA1/2-test results between proband and relatives. Fam Cancer 10(1):87-96

58. Feldman-Stewart D, Brundage MD, Tishelman C (2005) A conceptual framework for patientprofessional communication: an application to the cancer context. Psychooncology 14(10):801-809

59. Pieterse A, Ausems M, Spreeuwenberg P, Van Dulmen S (2011) Longer-term influence of breast cancer genetic counseling on cognitions and distress: smaller benefits for affected versus unaffected women. Patient Educ Couns (in press)

60. Colvin Clark RC, Mayer RE (2008) E-learning and the science of instruction. Wiley, San Francisco 
Albada, A., Dulmen, S. van, Lindhout, D., Bensing, J.M., Ausems, M.G.E.M. A pre-visit tailored website enhances counselees' realistic expectations and knowledge and fulfils information needs for breast cancer genetic counselling. Familial Cancer: 2012, 11(1), 85-95

\section{FIGURES AND TABLES}

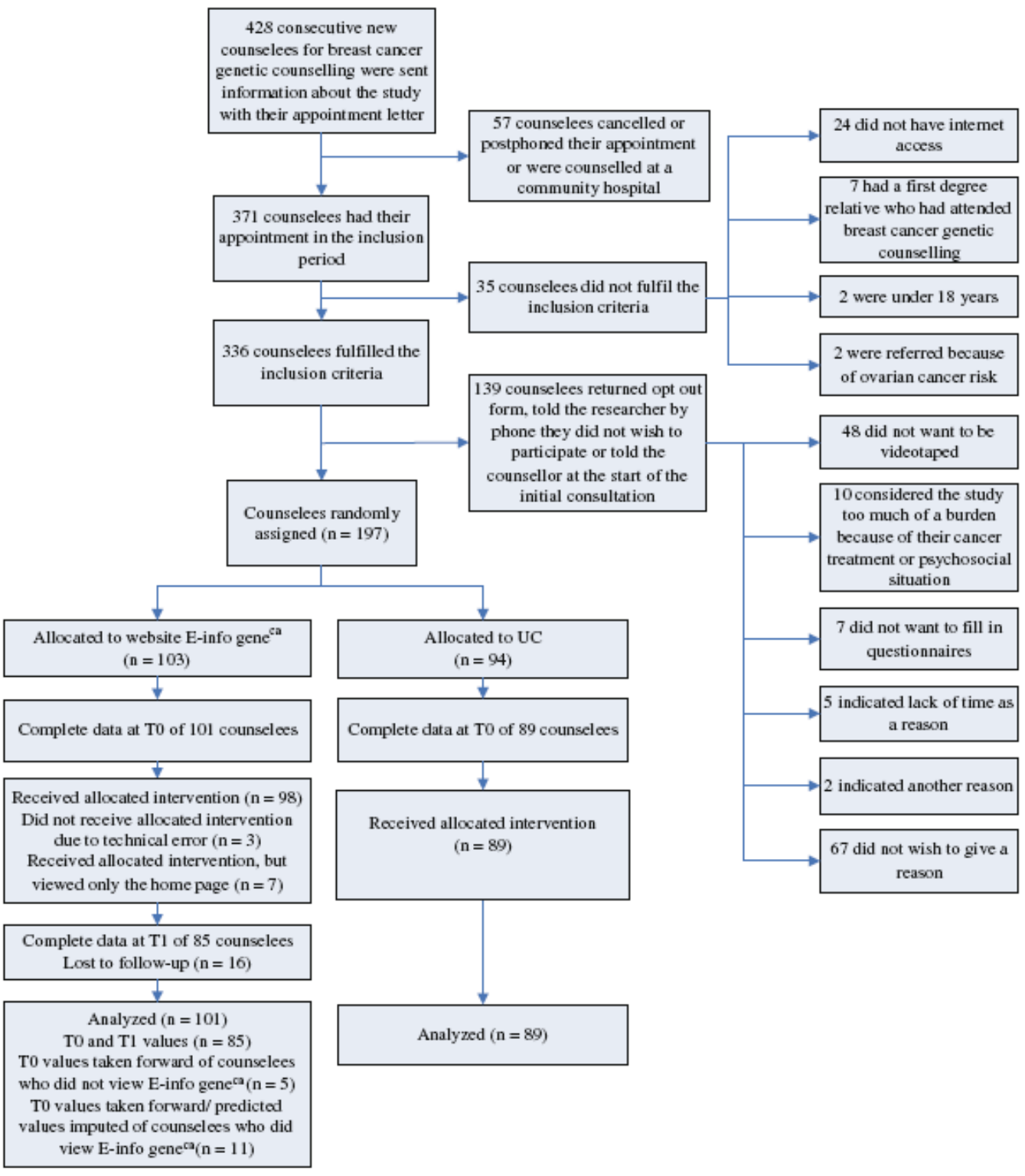

Fig. 1 Flow diagram 
Albada, A., Dulmen, S. van, Lindhout, D., Bensing, J.M., Ausems, M.G.E.M. A pre-visit tailored website enhances counselees' realistic expectations and knowledge and fulfils information needs for breast cancer genetic counselling. Familial Cancer: 2012, 11(1), 85-95

A. Albada et al.

\begin{tabular}{|c|c|c|c|c|c|c|c|c|c|}
\hline & \multicolumn{4}{|c|}{ UC group ( $n=89$ ) } & \multicolumn{4}{|c|}{ Intervention group $(n=101)$} & \multirow[t]{2}{*}{$P$} \\
\hline & $n$ & $\%$ & Mean & SD range & $n$ & $\%$ & Mean & SD range & \\
\hline Age (years) $(\text { age } \leq 50)^{a}$ & 71 & 79.78 & 41.18 & $\begin{array}{l}11.76 \\
21-68\end{array}$ & 75 & 74.26 & 41.76 & $\begin{array}{l}11.35 \\
21-69\end{array}$ & .82 \\
\hline 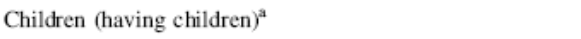 & 61 & 68.53 & & & 69 & 69.00 & & & .78 \\
\hline \multicolumn{10}{|l|}{ Educational attainment } \\
\hline University (MSc/BSc)/higher vocational education (BSc) & 42 & 47.19 & & & 36 & 35.64 & & & .22 \\
\hline Middle vocational education & 22 & 24.72 & & & 31 & 30.69 & & & \\
\hline High school/secondary education & 22 & 24.72 & & & 33 & 32.67 & & & \\
\hline$<$ High school level & 3 & 3.37 & & & 1 & .99 & & & \\
\hline \multicolumn{10}{|l|}{ Referral pathway } \\
\hline GP & 48 & 55.17 & & & 43 & 43.00 & & & .19 \\
\hline Specialist consultant UMC & 21 & 24.14 & & & 26 & 26.00 & & & \\
\hline Specialist consultant peripheral hospital & 18 & 20.69 & & & 31 & 31.00 & & & \\
\hline \multicolumn{10}{|l|}{ Initiative for referral } \\
\hline Counselee & 34 & 38.20 & & & 28 & 28.00 & & & .30 \\
\hline Both counselee and physician & 27 & 30.34 & & & 44 & 44.00 & & & \\
\hline Consultant & 18 & 20.22 & & & 18 & 18.00 & & & \\
\hline GP & 7 & 7.87 & & & 4 & 4.00 & & & \\
\hline Personal history of breast cancer (affected) ${ }^{\mathrm{a}}$ & 29 & 32.58 & & & 47 & 46.53 & & & .053 \\
\hline 1st degree relatives affected with breast cancer & 47 & 52.81 & & & 54 & 53.47 & & & .93 \\
\hline Risk of being $\mathrm{BRCA} 1 / 2$ mutation carrier (high) ${ }^{\mathrm{a}, \mathrm{b}}$ & 39 & 46.99 & & & 43 & 43.88 & & & .72 \\
\hline
\end{tabular}

UC usual care, UMC University Medical Center

a Variables used to tailor the information on the website E-info gene ${ }^{\text {ca }}$

${ }^{b}$ Algorithm for this tailoring variable: IF (bc affected AND age at diagnosis $\leq 40$ ) OR (bc affected AND oc affected) OR (bc affected AND first/second degree family members affected with oc) OR (number of first degree family members affected with bc $>1$ ) OR (number of first degree family members affected with oc $\geq 1$ ) OR (first/second degree family members affected with bc AND first/second degree family members affected with oc) OR (bilateral bc AND $1^{\text {st }}$ diagnosis at age $<50$ ) OR (oc affected AND first/second degree family members affected with bc): risk of being BRCA1/2 mutation carrier = high

an indication for DNA-testing and the possibility of an inconclusive DNA-test outcome was assessed with two items. Finally, information needs were assessed at T0 and T1 with the QUOTE-gene ${ }^{\text {ca }}[14]$. The items referred to explanations counselees wanted to receive during the first consultation and were answered on a 4-point scale (not based on the items of the QUOTE-gene ${ }^{c a}$ (see Table 4). The coders were blinded for the intervention/UC condition. The first $30 \%$ of the responses were coded independently by both the first (AA) and the last author (MA). Agreement between coders was $80 \%$. Disagreements were discussed and AA coded the remaining $70 \%$ of the responses. 
Albada, A., Dulmen, S. van, Lindhout, D., Bensing, J.M., Ausems, M.G.E.M. A pre-visit tailored website enhances counselees' realistic expectations and knowledge and fulfils information needs for breast cancer genetic counselling. Familial Cancer: 2012, 11(1), 85-95

Table 2 Topics of counselees' expectations concerning their first visit for breast cancer genetic counselling

\begin{tabular}{|c|c|c|c|c|c|}
\hline \multirow[t]{2}{*}{ 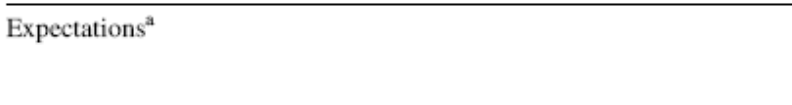 } & \multicolumn{2}{|c|}{ UC group $(n=86)^{\mathrm{b}}$} & \multicolumn{2}{|c|}{ Intervention group $(n=78)^{\mathrm{c}}$} & \multirow[t]{2}{*}{$P^{*}$} \\
\hline & $n$ & $\%$ & $n$ & $\%$ & \\
\hline Don't know what to expect & 7 & 8.14 & 1 & 1.28 & .04 \\
\hline \multicolumn{6}{|l|}{ Unrealistic expectations } \\
\hline DNA-test (irrespective of risk profile) & 13 & 15.12 & 4 & 5.13 & .03 \\
\hline Certainty about whether the breast cancer in the family is hereditary & 9 & 10.47 & 9 & 11.54 & .92 \\
\hline Knowing whether I am a carrier & 18 & 20.93 & 9 & 11.54 & .08 \\
\hline \multicolumn{6}{|l|}{ Realistic expectations } \\
\hline $\begin{array}{l}\text { Get to know more about whether there is an indication } \\
\text { for DNA-testing in the family }\end{array}$ & 0 & .00 & 8 & 10.26 & .007 \\
\hline \multicolumn{6}{|l|}{ Information/advice about } \\
\hline Counselee's own risk & 44 & 51.16 & 39 & 50.00 & .13 \\
\hline Family members' risk & 11 & 12.79 & 18 & 23.08 & .41 \\
\hline The procedure of genetic counselling & 19 & 22.09 & 9 & 11.54 & .02 \\
\hline Options for breast cancer screening & 14 & 16.28 & 9 & 11.54 & .15 \\
\hline Possibilities of DNA-testing & 12 & 13.95 & 12 & 15.39 & .74 \\
\hline The meaning of being carrier of a BRCA $1 / 2$ mutation & 6 & 6.98 & 3 & 3.85 & .22 \\
\hline Indications for hereditary breast cancer & 10 & 11.63 & 3 & 3.85 & .02 \\
\hline Inheritance of breast cancer & 3 & 3.49 & 6 & 7.69 & .41 \\
\hline
\end{tabular}

* Between-group differences of UC and intervention group

${ }^{\text {a }}$ More than one expectation is possible

${ }^{b}$ Three missing values

${ }^{\mathrm{c}}$ Seven missing values

Table 3 Counselees' level of accurate knowledge about breast cancer and heredity

\begin{tabular}{|c|c|c|c|c|c|c|c|c|}
\hline \multirow[t]{3}{*}{ Scale } & \multicolumn{4}{|c|}{ Baseline ( $\mathrm{T} 0$ ) } & \multirow{2}{*}{\multicolumn{2}{|c|}{$\begin{array}{l}\text { Post-website (T1) } \\
\text { Intervention } \\
\text { group }(n=90)\end{array}$}} & \multirow[t]{3}{*}{$P^{*}$} & \multirow[t]{3}{*}{$P^{* *}$} \\
\hline & \multicolumn{2}{|c|}{$\begin{array}{l}\text { UC group } \\
(n=89)\end{array}$} & \multicolumn{2}{|c|}{$\begin{array}{l}\text { Intervention } \\
\text { group }(n=101)\end{array}$} & & & & \\
\hline & Mean & SD & Mean & SD & Mean & SD & & \\
\hline Accurate knowledge $(0-7)^{*}$ & 4.65 & 1.46 & 4.64 & 1.60 & 5.29 & 1.39 & .003 & .000 \\
\hline \multirow[t]{2}{*}{ True/false knowledge items } & \multicolumn{2}{|c|}{ Correct answer } & \multicolumn{2}{|c|}{ Correct answer } & \multicolumn{2}{|c|}{ Correct answer } & & \\
\hline & $n$ & $\%$ & $n$ & $\%$ & $n$ & $\%$ & & \\
\hline $\begin{array}{l}\text { Early detection and treatment of be lead to longer survival } \\
\text { than late detection and treatment (true) }\end{array}$ & 86 & 96.63 & 98 & 97.03 & 89 & 98.89 & .24 & .37 \\
\hline $\begin{array}{l}\text { All women who are carrier of an altered gene (mutation) } \\
\text { for bc, will develop bc in the long term (false) }\end{array}$ & 39 & 43.82 & 47 & 46.53 & 54 & 61.36 & .01 & .04 \\
\hline $\begin{array}{l}\text { A woman who has a sister with an altered gene (mutation) for } \\
\text { bc, has a } 50 \% \text { chance ( } 1 \text { in } 2 \text { ) to also carry the mutation } \\
\text { herself (true) }\end{array}$ & 31 & 35.23 & 34 & 33.66 & 42 & 47.73 & .02 & .049 \\
\hline $\begin{array}{l}\text { A woman who does not have an altered gene (mutation) } \\
\text { for bc, can nevertheless develop bc (true) }\end{array}$ & 70 & 78.65 & 77 & 77.78 & 73 & 81.11 & .39 & .57 \\
\hline $\begin{array}{l}\text { Physical examination is necessary only when you have } \\
\text { complaints; at that point it is soon enough to prevent } \\
\text { bc (false) }\end{array}$ & 84 & 94.38 & 93 & 93.00 & 80 & 88.89 & .24 & .32 \\
\hline $\begin{array}{l}\text { If a father has an altered gene (mutation) for bc, then his } \\
\text { children have } 50 \% \text { chance ( } 1 \text { in } 2 \text { ) of also having this } \\
\text { mutation (true) }\end{array}$ & 27 & 30.34 & 38 & 37.62 & 49 & 56.32 & .003 & .01 \\
\hline $\begin{array}{l}\text { If in a family, in which be frequently occurs, no altered } \\
\text { gene (mutation) for be is found, then regular breast } \\
\text { surveillance is no longer necessary (false) }\end{array}$ & 77 & 86.52 & 82 & 81.19 & 80 & 88.89 & .33 & .14 \\
\hline
\end{tabular}

$U C$ usual care

* Between-group differences of UC and intervention group; ** within-group differences of intervention group baseline versus T1 
Albada, A., Dulmen, S. van, Lindhout, D., Bensing, J.M., Ausems, M.G.E.M. A pre-visit tailored website enhances counselees' realistic expectations and knowledge and fulfils information needs for breast cancer genetic counselling. Familial Cancer: 2012, 11(1), 85-95

Table 4 Counselees' information needs concerning breast cancer genetic counselling

\begin{tabular}{|c|c|c|c|c|c|c|c|c|}
\hline & \multicolumn{4}{|c|}{ Baseline (T0) } & \multirow{2}{*}{\multicolumn{2}{|c|}{$\begin{array}{l}\text { Post-website (T1) } \\
\text { Intervention } \\
\text { group }(n=90)\end{array}$}} & \multirow[t]{3}{*}{$P^{*}$} & \multirow[t]{3}{*}{$P^{* * *}$} \\
\hline & \multicolumn{2}{|c|}{$\begin{array}{l}\text { UC group } \\
(n=89)\end{array}$} & \multicolumn{2}{|c|}{$\begin{array}{l}\text { Intervention } \\
\text { group }(n=101)\end{array}$} & & & & \\
\hline & Mean & SD & Mean & SD & Mean & SD & & \\
\hline Information needs (1-4) & 3.12 & .38 & 3.10 & .41 & 2.96 & .46 & .000 & .001 \\
\hline
\end{tabular}

Factors and items

'During the counselling, the counsellor should provide information about...'

\begin{tabular}{|c|c|c|c|c|c|c|c|c|}
\hline Procedural aspects of counselling & 2.93 & .52 & 2.82 & .58 & 2.73 & .59 & .000 & .047 \\
\hline Clear division of roles between counsellors & 3.19 & .58 & 3.08 & .67 & 2.86 & .70 & .003 & .01 \\
\hline How long the diagnostic procedure takes & 2.87 & .74 & 2.70 & .83 & 2.71 & .74 & .48 & .24 \\
\hline Communication with family members & 2.72 & .74 & 2.65 & .79 & 2.49 & .72 & .10 & .02 \\
\hline Emotional aspects of the diagnostic procedure & 2.96 & .74 & 2.86 & .88 & 2.63 & .81 & .008 & .000 \\
\hline Determination and meaning of being a carrier of a cancer gene & 3.32 & .47 & 3.33 & .49 & 3.23 & .55 & .03 & .054 \\
\hline Possibilities of DNA-testing & 3.23 & .69 & 3.25 & .62 & 3.20 & .69 & .26 & .44 \\
\hline Limitations of DNA-testing & 3.17 & .74 & 3.23 & .63 & 3.12 & .72 & .03 & .07 \\
\hline Procedure of DNA-testing & 3.21 & .68 & 3.18 & .67 & 3.10 & .72 & .10 & .18 \\
\hline What it means to be a carrier of a breast cancer gene & 3.43 & .56 & 3.49 & .58 & 3.34 & .67 & .055 & .11 \\
\hline Why the counselee is (not) considered for further examination & 3.55 & .52 & 3.44 & .50 & 3.33 & .50 & .04 & .10 \\
\hline What it means to be a carrier of a certain gene & 3.32 & .58 & 3.41 & .60 & 3.27 & .70 & .15 & .28 \\
\hline Emotional aspects for counselee and family & 3.13 & .55 & 3.08 & .59 & 2.87 & .55 & .000 & .000 \\
\hline Emotional consequences of genetic counselling for the family & 3.17 & .73 & 3.08 & .82 & 2.83 & .78 & .000 & .001 \\
\hline Emotional consequences of genetic counselling for the counselee & 3.06 & .77 & 2.99 & .84 & 2.81 & .78 & .000 & .001 \\
\hline Procedure of analysis of the family history & 3.38 & .57 & 3.39 & .57 & 3.06 & .31 & .04 & .04 \\
\hline What it means not to be a carrier of a cancer gene & 3.11 & .63 & 3.20 & .75 & 2.90 & .86 & .001 & .003 \\
\hline Own risk of developing breast cancer & 3.44 & .47 & 3.46 & .56 & 3.36 & .58 & .13 & .14 \\
\hline $\begin{array}{l}\text { What to do if the counselee has an increased risk of developing } \\
\text { breast cancer }\end{array}$ & 3.70 & .46 & 3.69 & .52 & 3.63 & .53 & .21 & .32 \\
\hline $\begin{array}{l}\text { What to do if the counselee does not have an increased risk } \\
\text { of developing breast cancer }\end{array}$ & 3.18 & .67 & 3.23 & .73 & 3.06 & .79 & .04 & .03 \\
\hline Heredity of breast cancer & 2.67 & .53 & 2.80 & .53 & 2.67 & .70 & .07 & .12 \\
\hline The prevalence of breast cancer & 2.35 & .77 & 2.29 & .75 & 2.31 & .89 & .76 & .65 \\
\hline How often is breast cancer hereditary & 2.76 & .66 & 2.84 & .66 & 2.72 & .77 & .34 & .37 \\
\hline How breast cancer inherits in a family & 3.18 & .62 & 3.27 & .55 & 3.00 & .75 & .001 & .002 \\
\hline
\end{tabular}

UC usual care

* Between-group differences of UC and intervention group; ** within-group differences of intervention group baseline versus T1 